\title{
PRODUCTIVE RESPONSES FROM BROILER CHICKENS RAISED IN DIFFERENT COMMERCIAL PRODUCTION SYSTEM - PART II: IMPACT OF CLIMATE CHANGE
}

\author{
Dian Lourençoni ${ }^{*}$, Tadayuki Yanagi Junior ${ }^{2}$, Silvia de N. M. Yanagi², Paulo G. de Abreu ${ }^{3}$, \\ Alessandro T. Campos ${ }^{2}$
}

\author{
${ }^{1 *}$ Corresponding author. Universidade Federal do Vale do São Francisco/ Juazeiro - BA, Brasil. \\ E-mail: dian.lourenconi@univasf.edu.br ORCID ID: https://orcid.org/0000-0003-1173-2381
}

KEYWORDS
broiler industry,
artificial intelligence,
climate change, fuzzy
system.

\begin{abstract}
Broiler chickens are homoeothermic animals, i.e., animals capable of maintaining their body temperature within quite narrow limits; therefore, climate change poses a great challenge to poultry. With this in mind, this research aims to evaluate the performance of broilers submitted to different commercial production systems and exposed to different future scenarios, taking into account the climate change trends. To achieve this objective, we developed and validated a fuzzy model able to predict the performance of a broiler as a function of enthalpy along its life stages. This model was developed and validated in part I of this article based on experimental data collected for one year in three aviaries: conventional, negative pressure, and dark house systems. A Mann-Kendall nonparametric test and linear regression analysis were applied to the enthalpy values, which were calculated as a function of the ambient air temperature and relative humidity in order to study the climate change trends. Later, simulations were performed using the fuzzy model for 2025, 2050, 2075, and 2100 future scenarios. Specific improvements were observed when the heating trends coincided with the initial stages of breeding; however, in general, the productive responses of broilers in the different evaluated systems worsened with the climate change trends. Faced with the climate change trends, the responses improved in the order dark house aviary $>$ negative pressure aviary $>$ conventional aviary.
\end{abstract}

\section{INTRODUCTION}

The high temperature and air relative humidity values in tropical and semi-tropical climates, such as in Brazil, offer thermal discomfort conditions to chickens, decreasing their productive performance (Baracho et al., 2013; Boiago et al., 2013; Lara \& Rostagno, 2013; Castro, 2014; Santos et al., 2014). The breeding environment, in the case of broilers, is one of the major causes of losses in commercial scale animal production. Several authors highlight that, for high genetic potential animals, it is necessary to provide adequate nutritious food and an aseptic environment thermally adjusted to the chicken's needs in order to allow them to express their full potential (Abreu et al., 2012, Almeida \& Passini, 2013; Campos et al., 2013b; Nascimento et al., 2014; Tinôco et al., 2014).

Climate change poses a major challenge to the Brazilian poultry, as the chickens, which are homoeothermic animals, i.e., animals able to maintain their body temperature within quite narrow limits, suffer considerable productive losses when the thermal environment exceeds their comfort limits (Baracho et al., 2013; Boiago et al., 2013; Lara \& Rostagno, 2013; Castro, 2014; Santos et al., 2014).

Broiler production is negatively affected by increases in gas emissions (Carbon dioxide - $\mathrm{CO}_{2}$, Methane $-\mathrm{CH}_{4}$, Nitrous Oxide - $\mathrm{N}_{2} \mathrm{O}$, Chlorofluorocarbons - CFC-11, and CFC-12) responsible for the greenhouse effect (Gomes et al., 2011). Penereiro et al. (2012) reported that around $40 \%$ of the capitals of Brazilian states experienced an average temperature rise trend; four of them are located in the North region, two in the North-East region, two in the Midwest region, one in the South-East, and one in the South, the latter being Curitiba, Paraná, Brazil. Silva \& Streck (2014) evaluated the climate change for the city of Santa Maria, Rio Grande do Sul, Brazil, through its monthly

\footnotetext{
${ }^{2}$ Universidade Federal de Lavras/ Lavras - MG, Brasil.

${ }^{3}$ Embrapa Suínos e Aves/ Concordia - SC, Brasil.

Received in: 7-11-2018

Accepted in: 10-29-2018
} 
average heat index using the Mann-Kendall non-parametric test. Their results revealed that, in the months of March, at 9 am, and January, March, April, and November, at 3 pm, there is a significant positive trend, while the months of September, at $3 \mathrm{pm}$, and August, at $9 \mathrm{pm}$, have a negative trend. The most adequate method to study climate change in climatological series is the Mann-Kendall test (Goossens \& Berger, 1986).

Therefore, the projection of broiler performance in places exposed to climate change is essential for improving the maintenance mechanisms responsible for keeping the thermal environment within the comfort intervals for genetic screening in order to explore the genetic potential of the lineage. For this purpose, it is necessary to develop environment control algorithms (mathematical models) that can be embedded in microcontrollers. Among the possible models to be developed, those based on artificial intelligence, specifically on the fuzzy set theory, have been adequate in animal comfort research (Gates et al., 2001; Castro et al., 2012; Ponciano et al., 2012; Campos et al., 2013a; Aborisade \& Stephen, 2014; Ferraz et al., 2014; Xiang-Jie, 2014; Julio et al., 2015; Mirzaee-Ghalehv et al., 2015; Schiassi et al., 2015; Zare Mehrjerdi et al., 2015).

However, most fuzzy modeling studies have been individually carried out in one production system or in laboratories, where the environmental conditions are controlled. Thus, the fuzzy modeling conducted under these conditions may have limitations when applied to production systems different from the ones used in the studies. Among the existing broiler production systems, we can highlight the conventional system, the negative pressure system, and the dark house system.

The development of a mathematical fuzzy model based on different commercial production systems and on a given number of broilers raised in these systems shall forecast the broilers' performance independently of the utilized system in different climate change scenarios.

In this context, the objective of this research was to apply a fuzzy model capable of predicting the performance of broiler chickens raised in different commercial production systems to simulate future scenarios considering possible climatic changes in the State of Santa Catarina.

\section{MATERIAL AND METHODS}

\section{The fuzzy model}

The fuzzy model applied to the simulations was developed based on data from three aviaries: the conventional, the tunnel with negative pressure, and the dark house breeding systems. The data were obtained from six batches for each system over the course of a year.

The fuzzy model considers the enthalpies as input data in five stages of breeding: Stage 1 (first week of life), stage 2 (second week of life), stage 3 (third week of life), stage 4 (fourth and fifth weeks of life), and stage 5 (from the sixth week of life on). Stages 1, 2, and 3 correspond to the initial breeding phase; stage 4 refers to the growing phase, and stage 5 is the termination phase. The output variables correspond to the productive responses of the broilers, food intake (FI), average weight gain (WG), average feed conversion (FC), and productive efficiency index (PEI).

Mamdani's inference method (Ponciano et al., 2012; Lin et al., 2013; Julio et al., 2015; Schiassi et al., 2015) and the defuzzification method using the center of gravity (Leite et al., 2010) were used. Two hundred and forty-three rules with weighting factors of 1.0 were elaborated (Yanagi Junior et al., 2012; Ponciano et al., 2012; Schiassi et al., 2013; Schiassi et al., 2014). Trapezoidal pertinence curves were utilized to represent the input (Schiassi et al., 2015) and the output variables.

The developed fuzzy model anticipates FI, WG, FC, and PEI with mean standard deviations and percentage errors of $4.16 \mathrm{~g}$ and $5.05 \%, 146.53 \mathrm{~g}$ and $8.04 \%, 0.06 \mathrm{~g} \mathrm{~g}^{-1}$ and $4.96 \%$, and 24.51 and $12.29 \%$, respectively. Additional details on the development and validation of the fuzzy model are available in Part I of this paper.

\section{Mann-Kendall Test}

The Mann-Kendall non-parametric test initially proposed by Sneyers (1975) and the linear regression were applied to the historical enthalpy series (Ávila et al., 2014, Tian et al., 2016). The enthalpy values (Equation 1) were calculated from the mean monthly values of the dry bulb temperature and air relative humidity for the period from 1987 to 2015. The measurements were made at Embrapa Swine and Poultry Agrometeorological Station in Concórdia, Santa Catarina, Brazil.

$$
\mathrm{H}=1,006 \times \mathrm{t}_{\mathrm{db}}+\mathrm{W} \times\left(2501+1,805 \times \mathrm{t}_{\mathrm{db}}\right)
$$

Where,

$$
\begin{aligned}
& \mathrm{H} \text { stands for enthalpy }(\mathrm{kJ} \mathrm{kg} \text { dry air } \\
& \left.{ }^{-1}\right) \text {; } \\
& \mathrm{t}_{\mathrm{db}} \text { is the air dry bulb temperature }\left({ }^{\circ} \mathrm{C}\right) \text {, and } \\
& \mathrm{W} \text { is the mixing ratio }\left(\mathrm{kg}_{\text {water vapor }} \mathrm{kg}_{\text {dry air }}{ }^{-1}\right) .
\end{aligned}
$$

The mixing ratio was calculated by [eq. (2)] as a function of the current water vapor pressure (ea, $\mathrm{kPa})$ and the local atmospheric pressure $\left(\mathrm{P}_{\mathrm{atm}}, \mathrm{kPa}\right)$.

$$
\mathrm{W}=0,622 \times\left(\frac{e a}{P_{\text {atm }}}\right)
$$

The Mann-Kendall (MK) test uses the concept of sequential order comparison of the time series value with the remaining values, counting the number of times the remaining terms are above the value analyzed. The $\mathrm{S}$ statistic is obtained by expressions 3 and 4 .

$$
\mathrm{S}=\sum_{\mathrm{i}=2}^{\mathrm{n}} \sum_{\mathrm{j}=1}^{\mathrm{i}=1} \operatorname{sinal}\left(\mathrm{X}_{\mathrm{i}}-\mathrm{X}_{\mathrm{j}}\right)
$$

Where,

$$
\operatorname{sinal}(X i-X j)=\left\{\begin{array}{l}
-1, \text { for }(X i-X j)<0 \\
0, \text { for }(X i-X j)=0 \\
1, \text { for }(X i-X j)>0
\end{array}\right.
$$

The $\mathrm{S}$ statistic tends to normality for high $\mathrm{n}$, with mean and variance given by Expressions 5 and 6 , respectively.

$$
\begin{aligned}
& \mathrm{E}(\mathrm{S})=0 \\
& \operatorname{Var}(\mathrm{S})=\frac{1}{18}[n(n-1)(2 n+5)]
\end{aligned}
$$

Where,

$n$ is the size of the time series. 
Therefore, the $Z_{\mathrm{MK}}$ statistic test is represented by Expression 7.

$$
Z_{\mathrm{MK}}= \begin{cases}\frac{\mathrm{S}-1}{\sqrt{\operatorname{Var}(\mathrm{S})}}, & \text { if } \mathrm{S}>0 \\ 0, & \text { if } \mathrm{S}=0 \\ \frac{\mathrm{S}+1}{\sqrt{\operatorname{Var}(\mathrm{S})}}, & \text { if } \mathrm{S}<0\end{cases}
$$

By means of the $Z_{M K}$ value, we can verify the statistically significant trend in the time series, and this statistic is used to test the null hypothesis that no trend exists. From the positive or negative values of $Z_{\mathrm{MK}}$, it can be inferred if the data trend is increasing or decreasing. The significance level adopted was $5 \%$, and significance was determined using the $\mathrm{p}$-value test.

\section{Simulations}

The simulations were performed with the help of the MATLAB's Fuzzy Toolbox ${ }^{\circledR}$ software, 7.13.0.564 (R2011b) version, in which the entire modeling was designed (Part I of this article). The damping coefficient of the barns was calculated by means of the experimental enthalpy data measured inside the aviaries and in the external environment through the ratio between the external and internal enthalpies.

The years 2025, 2050, 2075, and 2100 were chosen as the future scenarios. The enthalpy increases for each future scenario were obtained by multiplying the angular coefficients of the linear regression applied to the enthalpy data series, for the months when climate change trends appear, by the number of years from 2016 on. Subsequently, the previously calculated enthalpy increase was added to the external enthalpy experimental data of each breeding stage, and the result was multiplied by the damping coefficient of each aviary. Then, the values of FI, WG, FC, and PEI were simulated using the fuzzy system developed and validated in part I of this article. The simulations were performed only for the batches raised in the months in which a trend of climate change was detected (February and June); the lots are identified in Table 1.

TABLE 1. Batches from each evaluated system and their respective evaluation periods.

\begin{tabular}{cccccc}
\hline & Conventional & \multicolumn{2}{c}{ Negative Pressure } & \multicolumn{2}{c}{ Dark House } \\
\hline Batch & Period & Batch & Period & Batch & Period \\
\hline 1 & Sep-Oct & 1 & Sep-Oct & 1 & Sep-Oct \\
2 & Nov-Dec & 2 & Nov-Dec & 2 & Oct-Nov \\
3 & Jan-Feb & 3 & Dec-Feb & 3 & Jan-Feb \\
4 & Feb-Mar & 4 & Feb-Mar & 4 & Feb-Mar \\
5 & Apr-May & 5 & Apr-May & 5 & Apr-May \\
6 & Jun-Jul & 6 & Jun-Jul & 6 & May-Jul \\
\hline
\end{tabular}

\section{RESULTS AND DISCUSSION}

The analysis of the Mann-Kendall trend test for the monthly average enthalpy shows that, for the city of Concórdia, there was an increasing tendency for the months of February and June, as shown in Figure 1. There was no climate change trend for the other months. Several authors have pointed out that climate change results in more frequent, more intense, and longer heat waves (Renaudeau et al., 2012, Skuce et al., 2013, Sossidou et al., 2014).

A.

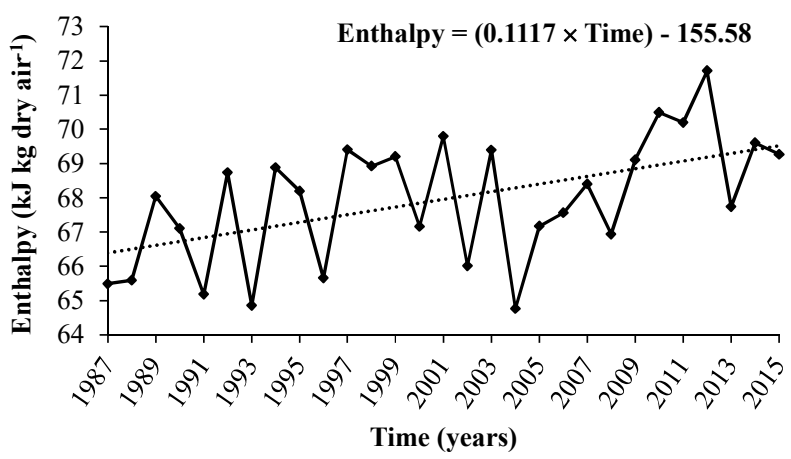

B.

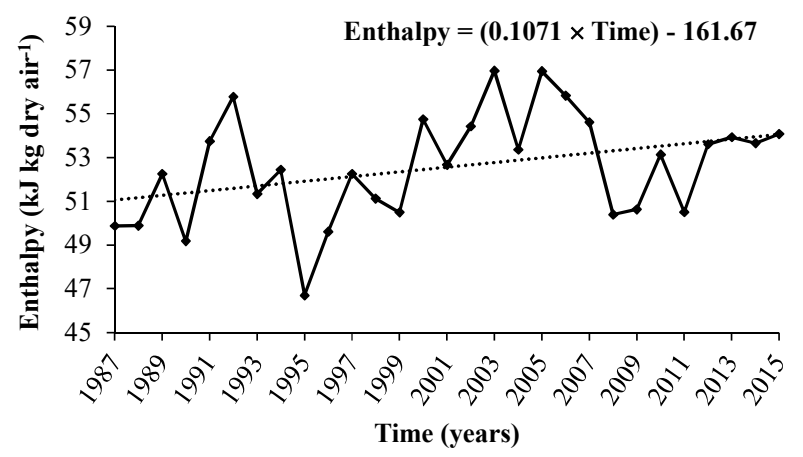

FIGURE 1. Time trend of enthalpy in February (A) and June (B) for the city of Concórdia, SC, Brazil, in the 1987-2015 period.

In a study conducted by Vale et al. (2016), in which the effect of heat waves on the thermal and aerial environment for broilers was simulated, it was noticed that temperature rises linearly increased the ammonia concentration and bed temperature. These authors also noticed that temperature rises linearly reduced the oxygen concentration in the air.
According to the heating trend scenarios for February and June, we can see, in Table 1, that the batches affected by these months were batches 3,4 , and 6 , and the productive performance results obtained by the fuzzy model for the batches affected by these months are shown in Table 2 . It can be seen that, for the 2025 scenario, all batches from the evaluated systems maintained the same productive performances. 
TABLE 2. Stages and batches affected by the climate change future scenarios and their respective food intake (FI, g), mean weight gain (WP, g), feed conversion ( $\mathrm{FC}, \mathrm{g} \mathrm{g}^{-1}$ ), and productive efficiency index (PEI) values predicted by the fuzzy model as functions of enthalpy and broilers' life stage for the future scenarios.

\begin{tabular}{|c|c|c|c|c|c|c|c|c|c|c|c|c|c|c|c|c|}
\hline \multirow{2}{*}{$\begin{array}{c}\text { Commercial } \\
\text { production } \\
\text { systems } \\
\end{array}$} & \multirow{2}{*}{ Batches } & \multicolumn{5}{|c|}{ Life stages } & \multicolumn{5}{|c|}{ FI } & \multicolumn{5}{|c|}{ WG } \\
\hline & & 1 & 2 & 3 & 4 & 5 & Current & 2025 & 2050 & 2075 & 2100 & Current & 2025 & 2050 & 2075 & 2100 \\
\hline \multirow{3}{*}{ Dark house } & 3 & & & & & & 117 & 117 & 117 & 113 & 112 & 2840 & 2840 & 2840 & 2750 & 2740 \\
\hline & 4 & & & & & & 117 & 117 & 123 & 120 & 116 & 2840 & 2840 & 3080 & 2960 & 2820 \\
\hline & 6 & & & & & & 114 & 114 & 114 & 111 & 105 & 2780 & 2780 & 2780 & 2700 & 2510 \\
\hline \multirow{3}{*}{ Conventional } & 3 & & & & & & 116 & 116 & 108 & 105 & 105 & 2830 & 2830 & 2600 & 2430 & 2430 \\
\hline & 4 & & & & & & 113 & 113 & 115 & 118 & 119 & 2770 & 2770 & 2790 & 2890 & 2920 \\
\hline & 6 & & & & & & 121 & 121 & 116 & 114 & 114 & 3010 & 3010 & 2820 & 2780 & 2770 \\
\hline \multirow{3}{*}{ Negative Pressure } & 3 & & & & & & 122 & 122 & 114 & 114 & 114 & 3070 & 3070 & 2770 & 2770 & 2770 \\
\hline & 4 & & & & & & 122 & 122 & 122 & 122 & 122 & 3030 & 3030 & 3030 & 3030 & 3030 \\
\hline & 6 & & & & & & 117 & 117 & 114 & 110 & 105 & 2840 & 2840 & 2770 & 2690 & 2430 \\
\hline \multirow{2}{*}{$\begin{array}{c}\text { Commercial } \\
\text { production } \\
\text { systems } \\
\end{array}$} & \multicolumn{6}{|c|}{ Life stages } & \multicolumn{5}{|c|}{ FC } & \multicolumn{5}{|c|}{ PEI } \\
\hline & Batches & 1 & 2 & 3 & 4 & 5 & Current & 2025 & 2050 & 2075 & 2100 & Current & 2025 & 2050 & 2075 & 2100 \\
\hline \multirow{3}{*}{ Dark house } & 3 & & & & & & 1.50 & 1.50 & 1.50 & 1.54 & 1.54 & 394 & 394 & 394 & 353 & 353 \\
\hline & 4 & & & & & & 1.50 & 1.50 & 1.43 & 1.49 & 1.50 & 394 & 394 & 409 & 399 & 394 \\
\hline & 6 & & & & & & 1.50 & 1.50 & 1.50 & 1.57 & 1.67 & 393 & 393 & 392 & 342 & 326 \\
\hline \multirow{3}{*}{ Conventional } & 3 & & & & & & 1.55 & 1.55 & 1.61 & 1.63 & 1.63 & 351 & 351 & 335 & 332 & 332 \\
\hline & 4 & & & & & & 1.52 & 1.52 & 1.53 & 1.53 & 1.49 & 370 & 370 & 363 & 359 & 397 \\
\hline & 6 & & & & & & 1.47 & 1.47 & 1.51 & 1.51 & 1.51 & 402 & 402 & 377 & 383 & 384 \\
\hline \multirow{3}{*}{ Negative Pressure } & 3 & & & & & & 1.44 & 1.44 & 1.50 & 1.50 & 1.50 & 408 & 408 & 392 & 392 & 392 \\
\hline & 4 & & & & & & 1.46 & 1.46 & 1.46 & 1.46 & 1.47 & 404 & 404 & 404 & 404 & 402 \\
\hline & 6 & & & & & & 1.51 & 1.51 & 1.53 & 1.58 & 1.63 & 388 & 388 & 363 & 340 & 332 \\
\hline
\end{tabular}

Stages highlighted in yellow correspond to batches raised during the month of February; the ones highlighted in blue correspond to batches raised in the month of June. Unchanged values are in green font, improved responses are in blue font, and worse responses are in red font.

The Conventional aviary displayed the worst productive responses in the 2050, 2075, and 2100 scenarios for batches 3 and 6 . Batch 4 exhibited the worst FC and PEI productive responses in the 2050 and 2075 scenarios. In turn, FI and WG in the 2050, 2075, and 2100 scenarios, and FC and PEI, in the 2100 scenario, showed improved productive responses for the respective batches.

The Negative Pressure aviary had the worst productive responses in the 2050, 2075, and 2100 scenarios for batches 3 and 6 . In batch 4, the FC and PEI results remained unchanged up to the 2075 scenario, while the FI and $\mathrm{WG}$ responses remained unchanged for all scenarios.

For the dark house aviary, the productive responses of almost all batches remained unchanged or improved until the 2050 scenario, with the exception of the PEI for 2050, which fell from 393 to 392 . We can see an improvement in batch 4 , in all productive responses, for the 2050 and 2075 scenarios.

Studies carried out by Vale et al. (2010) and Vale et al. (2016) show that the increase in temperature associated with the increase in ammonia concentration and reduction in oxygen availability during periods of heat waves may justify the increase in mortality in heat wave events or even offer reasonable explanations for the lower performance of broilers, as observed in this study.

In general, for all the evaluated confinement systems, batch 4, raised from February to March (Table 1), achieved the best results when exposed to the heating trends of the future scenarios. This was the only batch able to improve the productive responses to the heating trends for the dark house and conventional aviaries or to keep them unchanged for a longer time for the negative pressure aviary. These results can be explained as follows: the heating tendency coincided with the batch's initial production phase, when the broilers require a higher environment temperature condition (Menegali et al., 2013), and because they experience a cold stress condition, the warming trend of future scenarios brings an improvement in the production environment for these stages.

According to Cassuce et al. (2013), chickens submitted to cold stress during their growth stage change their behavior, which affects their physiological and metabolic functions, hence decreasing their productivity. 
In batches 3 and 6 , in which the warming trend affected the final production stages, we can see a worsening of productive results from the middle of the twenty-first century, when chickens suffered heat stress and, as a consequence, a drop in final batch performance, impairing the activity's profitability (Carvalho, 2012).

Observing the annual means of the productive responses of all 6 batches (Table 3 ) in the three barns, we noticed that the broilers raised in the dark house system achieved the best results when faced with climate change trends, followed by those in the negative pressure system and then those in the conventional system, findings that were expected due to the different control levels of the systems.

TABLE 3. Feed intake (FI, g), mean weight gain (WG, g), feed conversion (FC, $\mathrm{g} \mathrm{g}^{-1}$ ), and productive efficiency index (PEI) values as functions of enthalpy and broilers' life stages predicted by the fuzzy model for future scenarios.

\begin{tabular}{|c|c|c|c|c|c|c|c|}
\hline \multirow[b]{2}{*}{ Scenarios } & \multirow[b]{2}{*}{$\begin{array}{l}\text { Productive } \\
\text { response }\end{array}$} & \multicolumn{3}{|c|}{ Mean of affected batches } & \multicolumn{3}{|c|}{ Overall mean of all batches } \\
\hline & & Dark House & Conventional & $\begin{array}{l}\text { Negative } \\
\text { Pressure }\end{array}$ & Dark House & Conventional & $\begin{array}{l}\text { Negative } \\
\text { Pressure }\end{array}$ \\
\hline \multirow{4}{*}{ Current } & FI & 116 & 119 & 120 & 115 & 115 & 117 \\
\hline & WG & 2810 & 2947 & 2967 & 2800 & 2838 & 2893 \\
\hline & FC & 1.50 & 1.48 & 1.47 & 1.51 & 1.52 & 1.51 \\
\hline & PEI & 393 & 393 & 402 & 382 & 375 & 381 \\
\hline \multirow{4}{*}{2025} & FI & 116 & 117 & 120 & 115 & 114 & 117 \\
\hline & WG & 2820 & 2870 & 2980 & 2805 & 2800 & 2900 \\
\hline & FC & 1.50 & 1.51 & 1.47 & 1.51 & 1.54 & 1.51 \\
\hline & PEI & 394 & 374 & 400 & 382 & 365 & 380 \\
\hline \multirow{4}{*}{2050} & FI & 118 & 113 & 117 & 116 & 113 & 116 \\
\hline & WG & 2900 & 2737 & 2857 & 2845 & 2733 & 2838 \\
\hline & FC & 1.48 & 1.55 & 1.50 & 1.50 & 1.56 & 1.53 \\
\hline & PEI & 398 & 358 & 386 & 385 & 357 & 373 \\
\hline \multirow{4}{*}{2075} & FI & 115 & 112 & 115 & 115 & 112 & 115 \\
\hline & WG & 2803 & 2700 & 2830 & 2797 & 2715 & 2825 \\
\hline & FC & 1.53 & 1.56 & 1.51 & 1.53 & 1.56 & 1.54 \\
\hline & PEI & 365 & 358 & 379 & 368 & 357 & 370 \\
\hline \multirow{4}{*}{2100} & FI & 111 & 113 & 114 & 113 & 112 & 114 \\
\hline & WG & 2690 & 2707 & 2743 & 2740 & 2718 & 2782 \\
\hline & DC & 1.57 & 1.54 & 1.53 & 1.55 & 1.56 & 1.55 \\
\hline & PEI & 358 & 371 & 375 & 364 & 364 & 368 \\
\hline
\end{tabular}

Even with occasional improvements due to the effects of the heating trends of these months on the breeding stage, it is observed that there was a worsening in productive responses in the different evaluated systems. This reinforces the need for artificial thermal conditioning systems and the use of materials with greater thermal inertia, as well as their correct management, which would allow for a reduction in the thermal environment variations inside the aviaries and, consequently, the problems related to thermal discomfort (Santos et al., 2014).

According to the Broiler Performance and Nutrition Supplement (Cobb-Vantress, 2015), the cumulative feed conversion for male broilers at 42 days of age is around $1.667 \mathrm{~g} \mathrm{~g}^{-1}$. This study showed that, for all future scenarios, the estimated mean feed conversion values are below the value stipulated by the lineage index (Cobb-Vantress, 2015).

\section{CONCLUSIONS}

In light of the expected climate change trends for the months of February and June, with monthly average enthalpy increase for the state of Santa Catarina, the response results improved in the order dark house aviary $>$ negative pressure aviary $>$ the conventional aviary.
There were occasional improvements when the heating trends coincided with the initial stages of breeding; however, in general, there was a worsening of the productive responses in the different evaluated systems. Thus, the use of materials with higher thermal resistance and inertia values, and artificial thermal conditioning systems, as well as their correct management, can lead to a reduction in thermal environment variations inside the aviaries and, consequently, problems related to thermal discomfort.

\section{ACKNOWLEDGEMENTS}

The authors thank FAPEMIG, CAPES, CNPq and EMBRAPA Swine and Poultry for their support of this research.

\section{REFERENCES}

Aborisade DO, Stephen O (2014) Poultry house temperature control using Fuzzy-PID controller. International Journal of Engineering Trends and Technology 11(6):310-314. 
Abreu PG de, Abreu VMN, Coldebella A, Hassemer MJ, Tomazelli IL (2012) Medidas morfológicas em função do peso e da idade da ave, por meio de imagens. Revista Brasileira de Engenharia Agrícola e Ambiental 16(7):795801.

Almeida EA, Passini R (2013) Conforto térmico em modelos reduzidos de casas de frangos de corte, sob diferentes tipos de materiais de cobertura. Engenharia Agrícola 33(1):19-27.

Ávila LF, Mello CR, Yanagi SNM, Sacramento Neto OBS (2014) Tendências de temperaturas mínimas e máximas do ar no Estado de Minas Gerais. Pesquisa Agropecuária Brasileira 49(4):247-256.

Baracho MS, Cassiano JA, Nääs IA, Tonon GS, Garcia RG, Royer AFB, Santana MR (2013) Ambiente interno em galpões de frango de corte com cama nova e reutilizada. Agrarian 6(22):473-478.

Boiago MM, Barba H, Souza PA, Scatolini AM, Ferrari FB, Giampietro-Ganeco A (2013) Desempenho de frangos de corte, alimentados com dietas contendo diferentes fontes de selênio, zinco e manganês, criados sob condições de estresse térmico. Arquivo Brasileiro de Medicina Veterinária e Zootecnia 65(1):241-247.

Campos AT, Castro JO, Schiassi L, Yanagi Junior T, Pires MFÁ, Mattioli CC (2013a) Prediction of free-stall occupancy rate in dairycattle barns through fuzzy sets. Engenharia Agrícola 33(1):1079-1089.

Campos AT, Klosowski ES, Sousa FA, Ponciano PF, Navarini FC, Yanagi Junior T (2013b) Eficiência de sistema de aquecimento auxiliar para aviários, com base nos índices de conforto térmico. Bioscience Journal 29(3):703-711.

Carvalho LSS (2012) Nutrição de poedeiras em clima quente. Revista Científica Eletrônica de Medicina Veterinária 18:1-15.

Castro JO (2014) Avaliação e modelagem do desempenho de codornas japonesas em postura submetidas a diferentes ambientes térmicos. Tese Doutorado, Universidade Federal de Lavras.

Castro JO, Veloso AV, Yanagi Junior T, Fassani EJ, Schiassi L, Campos AT (2012) Estimate of the weight of Japanese quail eggs through fuzzy sets theory. Ciência e Agrotecnologia 36(1):108-116.

Cassuce DC, Tinoco IDF, Baeta FC, Zolnier S, Cecon PR, Vieira MDA (2013) Atualização da temperatura de conforto térmico para frangos de corte de até 21 dias de idade. Engenharia Agrícola 33(1):28-36.

COBB (2015) Suplemento de nutrição e desempenho do frango de corte: Cobb-Vantress, 14 p. Available in: http://www.cobb-vantress.com/ languages/guidefiles/fa217990-20c9-4ab1-a54e3bd02d974594_pt.pdf. Accessed: Jan 20, 2016.

Ferraz PFP, Yanagi Junior T, Julio YFH, Castro JO, Gates RS, Reis GM, Campos AT (2014) Predicting chick body mass with artificial intelligence-based models. Pesquisa Agropecuária Brasileira 49(7):559-568.
Gates RS, Chao K, Sigrimis N (2001) Identifying design parameters for fuzzy control of staged ventilation control systems. Computers and Electronics in Agriculture 31(1):61-74.

Gomes RCC, Yanagi Junior T, Lima RR, Yanagi SNM, Carvalho VF, Damasceno FA (2011) Predição do índice de temperatura do globo negro e umidade e do impacto das variações climáticas em galpões avícolas climatizados. Ciência Rural 41(9):1645-1651.

Goossens C, Berger A (1986) Annual and seasonal climatic variations over the northern hemisphere and Europe during the last century. Annales Geophysicae 4:385-400.

Julio YFH, Yanagi Junior T, Pires MFA, Lopes MA, Lima RR (2015) Fuzzy system to predict physiological responses of Holstein cows in southeastern Brazil. Revista Colombiana de Ciências Pecuárias 28(1):42-53.

Lara LJ, Rostagno MH (2013) Impacto do estresse térmico sobre a produção de aves. Animals 3(2):356-369.

Leite MS, Fileti AMF, Silva FV (2010) Desenvolvimento e aplicação experimental de controladores fuzzy e convencional em um bioprocesso. Revista Controle \& Automação 21(2):147-158.

Lin CS, Yeh PT, Chen DC, Chiou YC, Lee CH (2013) The identification and filtering of fertilized eggs with a thermal imaging system. Computers and Electronics in Agriculture 91:94-105.

Menegali I, Tinoco IFF, Carvalho CCS, Souza CF, Martins JH (2013) Comportamento de variáveis climáticas em sistemas de ventilação mínima para produção de pintos de corte. Revista Brasileira de Engenharia Agrícola e Ambiental 17(1):106-113.

Mirzaee-Ghalehv E, Omid M, Keyhani A, Dalvand MJ (2015) Comparison of fuzzy and on/off controllers for winter season indoor climate management in a model poultry house. Computers and Electronics in Agriculture 110:187-195.

Nascimento GR, Nääs IA, Baracho MS, Pereira DF, Neves DP (2014) Termografia infravermelho na estimativa de conforto térmico de frangos de corte. Revista Brasileira de Engenharia Agrícola e Ambiental 18(6):658-663.

Penereiro JC, Ferreira DHL, Garcia VFV (2012) Caracterização estatística de tendências climáticas em séries anuais de temperatura média e precipitação para as capitais Estaduais do Brasil. Revista GEINTEC 3(4):1-15.

Ponciano PF, Yanagi Junior T, Schiassi L, Campos AT, Nascimento JWB (2012) Sistema fuzzy para predição do desempenho produtivo de frangos de corte de 1 a 21 dias de idade. Engenharia Agrícola 32(3):446-458.

Renaudeau D, Collin A, Yahav S, Basilio V de, Gourdine JL, Collier RJ (2012) Adaptation to hot climate and strategies to alleviate heat stress in livestock production. Animal 6(5):707-728.

Santos GB, Sousa IF, Brito CO, Santos VS, Barbosa RJ, Soares C (2014) Estudo biológico das regiões litorâneas, agreste e semiárida do estado de Sergipe para a avicultura de corte e postura. Ciência Rural 44(1):123-128. 
Schiassi L, Melo NSM, Tavares GF, Souza ÍP, Araújo HB, Della Giustina C (2013) Modelagem fuzzy em parâmetros de bem-estar humano. Nativa 1(1):8-12.

Schiassi L, Yanagi Junior T, Damasceno FA, Saraz JAO, Amaral AG (2014) Thermal-Acoustic Comfort Index for Workers of Poultry Houses Using Fuzzy Modeling. International Journal of Engineering Research and Applications 4(9):60-64.

Schiassi L, Yanagi Junior T, Reis GM, Abreu LHP, Campos AT, Castro JO (2015) Modelagem fuzzy aplicada na avaliação do desempenho de frangos de corte. Revista Brasileira de Engenharia Agrícola e Ambiental 19(2):140146.

Silva SD, Streck NA (2014) Tendências das séries históricas do índice de calor no município de Santa Maria - RS. Ciência Rural 44(8):1360-1366.

Skuce PJ, Morgan ER, van Dijk J, Mitchell M (2013) Animal health aspects of adaptation to climate change: beating the heat and parasites in a warming Europe. Animal 7(2):333-345.

Sneyers R (1975) Sur l'analyse statistique des séries d'observations. Genève, Secrétariat de l' Organisation Météorologique Mondiale.

Sossidou EN, Tsiplakou E, Zervas G (2014) Options for managing livestock production systems to adapt to climate change. Journal of Earth Science and Engineering 4(1):15427.
Tian Q, Prange M, Merkel U (2016) Precipitation and temperature changes in the major Chinese river basins during 1957-2013 and links to sea surface temperature. Journal of Hydrology 536(1):208-221.

Tinôco IFF, Souza CF, Baêta FC, Coelho DJR, Mendes MASA (2014) Ambiência e Instalações na Avicultura de Postura Brasileira - Avanços e Perspectivas. Animal Busineess Brasil 4(14):6-9.

Vale MM, Moura DJ, Nääs IA, Curi TMRC, Lima KAO (2016) Effect of a simulated heat wave in thermal and aerial environment broiler-rearing environment.

Engenharia Agrícola 36(2):271-280.

Vale MM, Moura DJ, Nääs IA, Pereira DF (2010) Characterization of heat waves affecting mortality rates of broilers between 29 days and market age. Brazilian Journal of Poultry Science 123(4):279-285.

Xiang-Jie N (2014) Research on the temperature control algorithm of the poultry farm. Applied Mechanics and Materials 602:1206-1209.

Yanagi Junior T, Schiassi L, Abreu LHP, Barbosa JA, Campos AT (2012) Procedimento fuzzy aplicado à avaliação da insalubridade em atividades agrícolas. Engenharia Agrícola 32(3):423-434.

Zare Mehrjerdi MR, Ziaabadi M, Ayatollahi Mehrgardi A, Dayani O (2015) Comparison of fuzzy and on/off controllers for winter season indoor climate management in a model poultry house. Journal of Livestock Science and Technologies 3(1):34-40. 